\title{
Implementasi Sistem Kendali Adaptif Pada Rangkaian MPPT Sebagai Catu Daya Node WSN
}

\section{The Adaptive Control System Implementation on The MPPT Circuit as WSN Node Power Supply}

\author{
Risa Farrid Christianti1 1,* \\ ${ }^{1}$ Program Studi Teknik Elektro, Fakultas Teknik Telekomunikasi dan Elektro, \\ Institut Teknologi Telkom Purwokerto \\ Jl. D.I.Panjaitan no.128 Purwokerto, Jawa Tengah, Indonesia \\ 1,*Penulis korespondensi: risa@ittelkom-pwt.ac.id
}

Received on 10-12-2018, accepted on 04-01-2019, published on 28-01-2019

\begin{abstract}
Abstrak
Implementasi wireless sensor network (WSN) yang merupakan bagian dari teknologi Internet of Things (IoT), membutuhkan sumber pencatuan terkendali yang dapat beroperasi secara kontinyu dan adaptif. Dengan adanya teknologi pembangkit listrik sel surya atau photovoltaic (PV), dapat memberikan peluang sumber pencatuan bagi sistem WSN di daerah yang jauh dari layanan sistem kelistrikan konvensional. Namun implementasi sel surya secara konvensional memiliki efisiensi yang rendah, karena sangat dipengaruhi oleh faktor eksternal, di antaranya adalah intensitas cahaya matahari. Sistem Maximum Power Point Tracker (MPPT) sering digunakan untuk mengatasi permasalahan tersebut. MPPT mampu mengoptimalkan kinerja sel surya sehingga menghasilkan efisiensi terbaik, dengan cara menjaga tegangan solar panel pada tegangan optimalnya (Vs $=\mathrm{Vm})$, serta memaksimalkan transfer daya dari solar panel ke baterai. Karena daya pada keluaran konverter merupakan hasil perkalian $\mathrm{Vb}$ dan $\mathrm{lb}$, sedangkan tegangan baterai diasumsikan konstan selama siklus pengendalian. Dalam penelitian ini, dilakukan perancangan dan implementasi sistem pencatuan WSN dengan sumber pencatuan dari sel surya dan rangkaian pengendalian MPPT. Perangkat berbasis mikropengendali sebagai pengatur titik daya maksimal (MPP) sel surya diimplementasikan dengan metode adaptif. Hasil yang didapatkan adalah tegangan keluaran MPPT berfluktuasi antara 3,28V hingga 9,27V untuk jangkauan tegangan masukan 3,4 hingga 9,67V.
\end{abstract}

Keywords: Adaptive algorithms, Maximum Power Point Tracker (MPPT) circuits, Power converters, Solar energy harvesting, Wireless sensor networks.

\section{Abstract}

Implementing the wireless sensor network (WSN), which is a part of the Internet of Things (IoT) technology, requires a controlled power supply that can operate continuously and adaptively. Solar cell power generation technology or photovoltaic (PV) can provide a source of power supply for the WSN system in areas far from conventional electricity system 
services. However, the implementation of conventional solar cells has low efficiency because it is strongly influenced by external factors, including the intensity of sunlight. The Maximum Power Point Tracker (MPPT) system is often used to overcome these problems. MPPT can optimize the performance of solar cells to produce the best efficiency by maintaining the solar panel voltage at its optimum voltage $(\mathrm{Vs}=\mathrm{Vm})$ and maximizing the transfer of power from the solar panel to the battery. Because the power on the converter output results from multiplying $\mathrm{Vb}$ and $\mathrm{Ib}$, the battery voltage is assumed to be constant during the control cycle. In this study, the design and implementation of the WSN rationing system with sources of solar cells and MPPT control circuits were carried out. Furthermore, micro control-based devices as a maximum power point regulator (MPP) of solar cells are implemented with adaptive methods. The results obtained are MPPT output voltage fluctuating between $3.28 \mathrm{~V}$ to $9.27 \mathrm{~V}$ for the input voltage range of 3.4 to $9.67 \mathrm{~V}$.

Keywords: Adaptive algorithms, Maximum Power Point Tracker (MPPT) circuits, Power converters, Solar energy harvesting, Wireless sensor networks.

\section{Pendahuluan}

Wireless Sensor Network (WSN) adalah sebuah jaringan yang menghubungkan beberapa perangkat seperti sensor node, router dan sink node. Sedangkan node sensor atau node WSN adalah simpul dalam jaringan sensor yang mampu melakukan beberapa pemrosesan, mengumpulkan informasi sensorik dan berkomunikasi dengan node lain yang terhubung dalam jaringan nirkabel. Kebutuhan energi untuk mensuplai teknologi Jaringan Sensor Nirkabel (WSN) inilah masalah utama yang akan ditangani dalam penelitian ini, atau bagian power source-nya, untuk memberikan efektivitas kinerja dalam berbagai aplikasi yang luas dan durasi penggunaan yang lama.

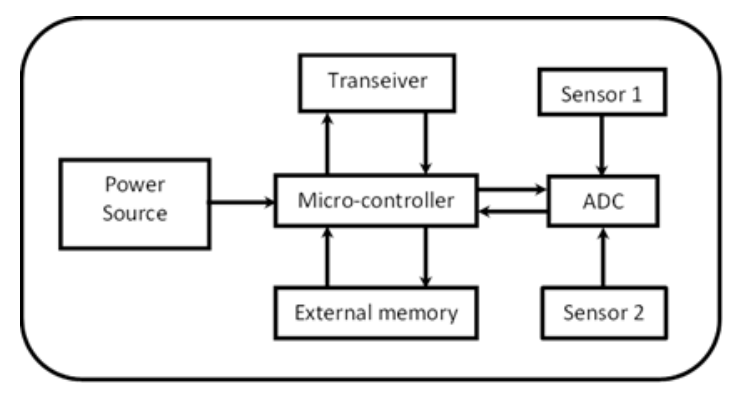

Gambar. 1 Arsitektur Node Wireless Sensor Network

Kenyataannya, node-node WSN kebanyakan diaplikasikan pada penggunaan di lapangan (outdoor) dalam durasi waktu operasi yang lama, namun hanya menggunakan baterai atau accu sebagai catu dayanya. Masih sangat jarang yang menggunakan pasokan sumber energi eksternal. Di sisi lain, node WSN merupakan ujung tombak sistem WSN yang membutuhkan performa kinerja yang tinggi sebagai pusat informasi dalam suatu sistem komunikasi.

Berdasarkan kenyataan tersebut, maka diharapkan ada suatu sistem yang dapat membuat node WSN bekerja secara optimal dan mampu bekerja dalam waktu operasi yang lama. Untuk itulah dibutuhkan sumber energi yang mampu mensuplai baterai agar node WSN selalu didukung dengan catu daya yang dapat bertahan lama dengan memanfaatkan energi surya. 


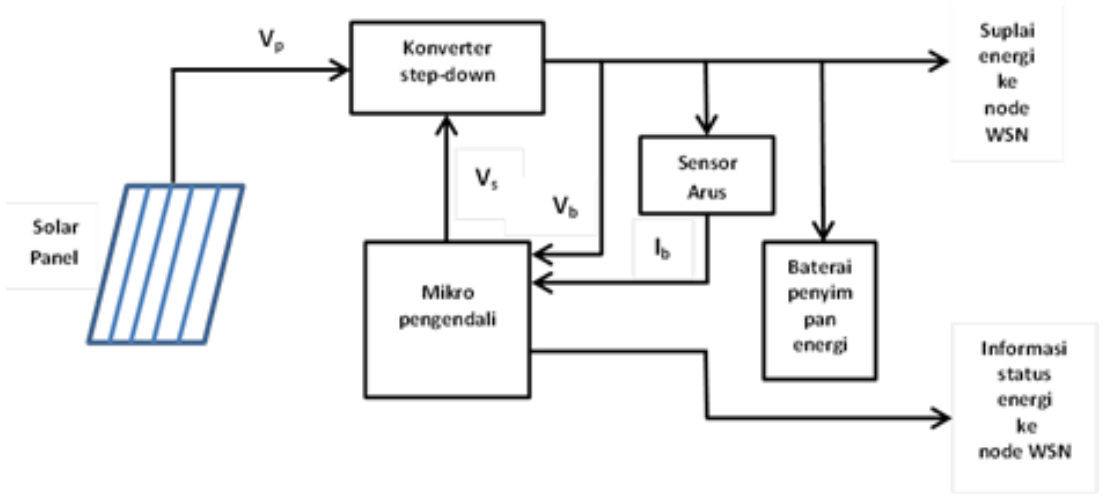

Gambar. 2 Diagram blok Sistem MPPT berbasis kendali adaptif.

\section{Tinjauan Pustaka}

Sistem daya Photo Voltaic (PV) atau yang sering disebut sistem Solar Cell merupakan satu dari teknologi energi terbarukan yang pertumbuhannya paling cepat, yang menyediakan sumber daya yang paling aman dan mensuplai listrik bebas polusi. Sayangnya, biaya fabrikasi sistem PV sangat tinggi dan efisiensi konversi energinya rendah. Karena kelistrikan PV yang mahal dibandingkan listrik dari PLN, maka penggunaan daya keluaran dari sistem PV secara maksimum sangat dibutuhkan[1].

Dalam penelitian-penelitian sebelumnya, ada solusi pemanenan energi surya untuk node WSN, dengan mekanisme pemuatan ambang batas ON/OFF sederhana dengan mengandalkan dioda yang menghubungkan solar cell dengan baterai isi ulang[2].

Sayangnya, solusi berbasis dioda mempunyai tiga kelemahan utama, yaitu :

1.

Titik kerja sel diatur oleh tegangan baterai dan tidak dapat disesuaikan untuk memaksimalkan perpindahan energi dalam perubahan lingkungan;

2.

Ambang batas mencegah sistem untuk beroperasi secara efisien di rating daya listrik rendah (selama kondisi surya tidak optimal);

3.

Karakteristik listrik dari sel surya harus dipilih untuk benar-benar sesuai dengan tegangan nominal baterai, jika tidak demikian, akan menghambat kinerja solar panel dan baterai.

Semua masalah tersebut dapat diatasi dengan mengganti rangkaian berbasis dioda dengan rangkaian MPPT. Filosofi desainnya menggunakan pengembangan sistem adaptif untuk mentransfer energi yang dihasilkan dari solar cell ke baterai yang berfungsi sebagai media penyimpanan, sambil mempertahankan titik kerja sel di kondisi optimalnya (dimana transfer dayanya dimaksimalkan).

Sistem PV harus dioperasikan pada daya keluaran maksimalnya (Maximum Power Point) dalam berbagai kondisi lingkungan. Titik operasi maksimumnya berada pada perpotongan kurva arus dan tegangan (I-V curves) pada sistem PV dan beban, saat sistem PV terhubung secara langsung ke beban. Titik daya maksimum dari sistem PV tidak tercapai setiap waktu. Masalah tersebut diatasi dengan menggunakan algoritma MPPT yang mempertahankan titik operasi sistem PV di titik daya maksimumnya. Ada beberapa algoritma pencarian MPPT yang telah banyak diusulkan dalam literatur yang menggunakan karakteristik solar panel dan lokasi titik daya maksimum yang berbeda, termasuk metode perturb and observe, metode open-and-circuit, algoritma konduktif inkremental, logika fuzzy dan jaringan syaraf tiruan[3].

Secara umum, rangkaian MPPT tradisional dibedakan berdasarkan desain kekuatan mengkonversi secara elektronik dan strategi kendalinya. Rangkaian konverter buck standar dan konverter boost DC to DC, serta kapasitor seri dan konfigurasi induktor telah dilaporkan[4][5][6]. MPPT telah dilakukan dengan pemodelan apriori dari sel[7][8], dengan loop kendali analog[9], atau melalui jaringan saraf tiruan dan logika Fuzzy[10]. Sayangnya, solusi ini tidak mengatasi tiga masalah utama terkait node WSN :

1. Ketersediaan sumber daya yang semakin lama semakin berkurang pada node;

2. Kebutuhan konsumsi daya MPPT yang sangat tinggi, sehingga sebagian besar energi yang dipanen tidak semuanya sampai ke baterai;

3. Tarif operasi daya yang sangat tinggi[11]. 
Dalam makalah ini, akan dijelaskan implementasi sistem adaptif yang dikendalikan secara digital oleh rangkaian MPPT, didesain khusus untuk node WSN. Desain dibuat sesuai dengan persyaratan dari target perangkat tertanam, yang memiliki : konsumsi daya yang sangat rendah dari MPPT, adaptasi cepat sesuai dengan perubahan lingkungan, efisiensi perpindahan energi tinggi dan biaya rendah.

Konverter DC-DC merupakan bagian inti dari rangkaian MPPT. Konverter DC-DC secara umum digunakan untuk mengubah dan mendistribusikan daya DC dalam suatu sistem. Untuk lebih jelasnya dapat dilihat diagram blok sistem konverter DC-DC pada gambar berikut[12] :

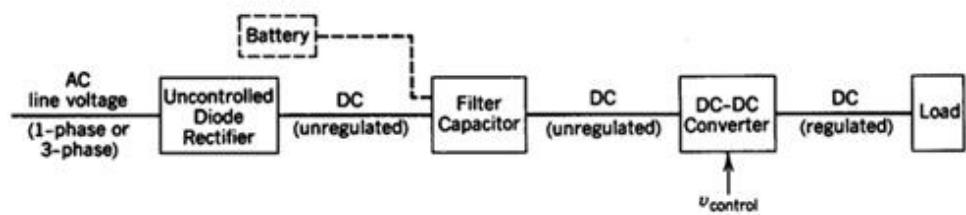

Gambar. 3 Sistem Konversi Tegangan DC-to-DC

(Source : Ned Mohan, "Power Electronics", Wiley and Sons Inc.)

Fungsi konverter DC-DC dalam sistem tersebut adalah sebagai berikut :

1. Mengubah tegangan masukan DC tidak terkendali menjadi tegangan keluaran DC terkendali.

2. Mengatur tegangan keluaran DC terhadap beban dan tegangan masukan DC yang bervariasi.

3. Mengurangi riak tegangan AC pada tegangan keluaran DC di bawah tingkat yang disyaratkan.

4. Menyediakan isolasi antara sumber masukan dan beban (isolasi tidak selalu dipenuhi).

5. Melindungi sistem yang disuplai dan sumber masukan dari gangguan elektromagnetik (EMI = Electro Magnetic Interference).

\section{Metode Penelitian}

\section{A. Perancangan Konverter Dengan Sistem Kendali Adaptif}

Pada prinsipnya, loop kendali rangkaian MPPT bertujuan menjaga tegangan keluaran solar panel berada pada tegangan referensi optimalnya, dengan memaksimalkan transfer daya dari solar cell ke baterai. Karena daya pada keluaran konverter adalah hasil perkalian antara tegangan dan arus baterai, serta tegangan baterai dapat dianggap konstan selama siklus kendali. Daya yang tersimpan proporsional dengan arus keluaran (dalam hal ini kendali memenuhi beberapa detik pada saat perintah Vb konstan selama 1 jam).

Rangkaian MPPT terdiri dari 2 blok logika utama :

1. Konverter daya yang dikendalikan tegangan, yang mengadaptasi sel surya dengan baterai untuk transfer daya.

2. Sistem kendali yang menjaga panel surya bekerja pada titik optimal (memaksimalkan pemanenan energi[11].

Konverter step-down secara elektronik menyesuaikan sel surya (menyediakan tegangan Vp) dengan baterai (dikarakterisasi oleh tegangan $\mathrm{Vb}$ ). Pada prinsipnya, tegangan $\mathrm{Vb}$ berbeda dari $\mathrm{Vp}$, tergantung dan ditetapkan oleh status pengisian baterai.

Sebaliknya, Vp bisa dikendalikan untuk meninggalkan daya $\mid$ IpVp ditransfer ke baterai ( $\mid$ adalah efisiensi konverter daya). Karena Vp dapat dikendalikan, maka tujuannya adalah mengatur Vp ke Vm, tegangan dimana daya yang ditransfer maksimum.

Lebih detail, tahap konverter daya yang diusulkan adalah modifikasi dari konverter step-down, sensor arus, dan mikropengendali. Tahapan perancangan dilakukan dalam dua tahap yaitu perancangan perangkat keras dan perangkat lunak. Perancangan perangkat keras meliputi proses perancangan model sistem berbasis aplikasi dan pengimplementasian model sistem. Perancangan perangkat lunak dilakukan setelah 
perancangan perangkat keras dilaksanakan. Sasaran akhir yang ingin dicapai yaitu sebuah perangkat embedded yang dapat menghasilkan daya untuk pencatuan WSN dengan spesifikasi yang telah ditetapkan.

Tabel 1. Jenis Dan Karakteristik Komponen Yang Digunakan

\begin{tabular}{|c|c|c|}
\hline No. & $\begin{array}{c}\text { Jenis } \\
\text { Komponen }\end{array}$ & Karakteristik Elektrik \\
\hline 1 & Solar Panel & $\begin{array}{c}\text { Daya }=10 \mathrm{~W} \pm 5 \% ; \text { Tegangan }=5 \\
-20 \mathrm{~V} ; \text { Arus }=0,55 \mathrm{~A}\end{array}$ \\
\hline 2 & Baterai Li-Po & $\begin{array}{c}\text { Daya }=16,28 \mathrm{WH} ; \text { Tegangan }= \\
7,64 \mathrm{~V} ; \text { Arus }=2200 \mathrm{mAh}\end{array}$ \\
\hline 3 & $\begin{array}{c}\text { Lampu LED } \\
\text { Flood Light }\end{array}$ & $\begin{array}{c}\text { Daya }=30 \mathrm{~W} ; \text { Lumens }=80 \mathrm{~lm} / \mathrm{W} ; \\
\mathrm{PF}=0,5\end{array}$ \\
\hline 4 & $\begin{array}{c}\text { Mikropengend } \\
\text { ali } \\
\text { ATMega328 }\end{array}$ & $\begin{array}{c}\text { Tegangan }=3-5 \mathrm{~V} \\
\end{array}$ \\
\hline 5 & $\begin{array}{c}\text { Sensor Arus } \\
\text { DT-sense }\end{array}$ & $\begin{array}{c}\text { Respon keluaran }=5 \mu \mathrm{s}, \\
\text { Bandwidth }=80 \mathrm{kHz}, \text { tegangan }= \\
5 \mathrm{~V}\end{array}$ \\
\hline
\end{tabular}

Tahapan perancangan dilakukan dalam dua tahap yaitu perancangan perangkat keras dan perangkat lunak. Perancangan perangkat keras meliputi proses perancangan model sistem berbasis aplikasi dan pengimplementasian model sistem menggunakan trainer board. Perancangan perangkat lunak dilakukan setelah perancangan perangkat keras dilaksanakan. Sasaran akhir yang ingin dicapai yaitu sebuah perangkat embedded yang dapat menghasilkan daya untuk pencatuan WSN dengan spesifikasi yang telah ditetapkan.

Untuk perancangan perangkat lunak, peneliti membuat gaftar alir sebagai acuan dalam membuat program berbasis sistem Adaptif, sebagai berikut :

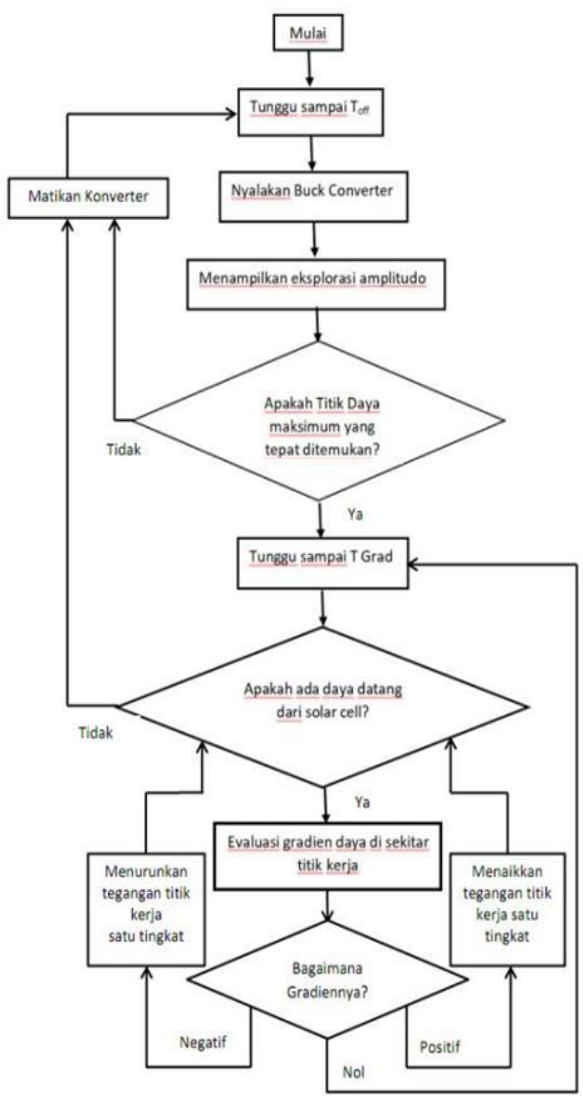

Gambar. 3 Algoritma kendali untuk mengidentifikasi dan mengadaptasi nilai Vs optimal. 


\section{B. Sistem Kendali Adaptif}

Pada dasarnya, loop kendali rangkaian MPPT bertujuan menjaga tegangan keluaran solar panel berada pada tegangan referensi optimalnya, dengan memaksimalkan transfer daya dari solar cell ke baterai. Karena daya pada keluaran konverter adalah hasil perkalian antara tegangan dan arus baterai, serta tegangan baterai dapat dianggap konstan selama siklus kendali. Daya yang tersimpan proporsional dengan arus keluaran (dalam hal ini kendali memenuhi beberapa detik pada saat perintah Vb konstan selama 1 jam).
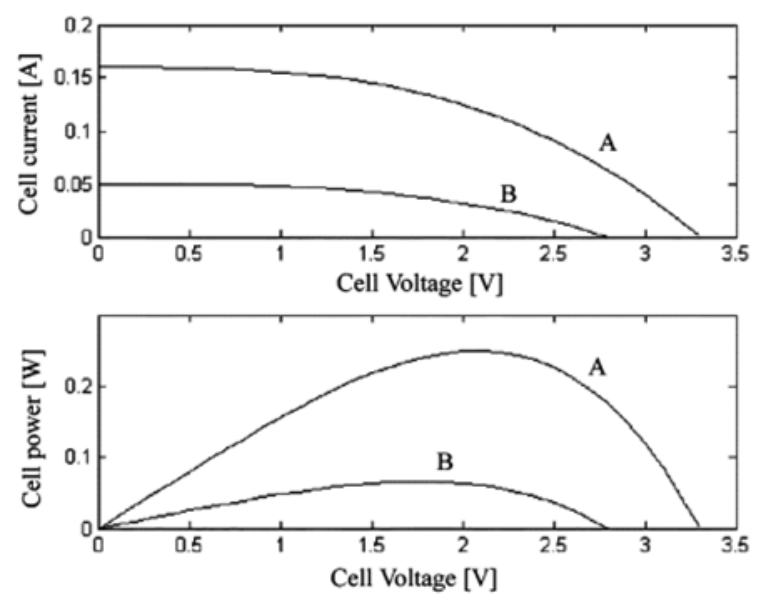

Gambar. 4 Karakteristik solar cell dalam 2 kondisi radiasi[11].

Gambar 4 menunjukkan dua jenis perilaku solar cell yang diiluminasikan dalam dua kondisi berbeda; arus dan daya yang dibangkitkan merupakan fungsi tegangan solar panel yang diberikan (dalam kurva A daya radiasinya lebih besar daripada kurva B). Apapun teknologi solar panelnya (inorganik atau organik), bentuk kurva daya versus tegangan cell $\mathrm{P}(\mathrm{Vp}$,Ip) menunjukkan perilaku conveks yang dikarakterisasi oleh suatu nilai maksimum unik yang berhubungan dengan fenomena transduksi energi.

Pada kenyataannya, algoritma kendali dalam eksekusi CPU harus diidentifikasi tegangan optimal Vmnya, dimana daya yang ditransmisikan maksimal dan mengacu pada perubahan kondisi, melacaknya, sehingga secara adaptif Vs konvergen ke Vm, yang sebagai gantinya akan berubah terhadap waktu. Tegangan optimal Vm pada waktu yang diberikan secara instan akan menjadi nilai referensi bagi loop kendali analog.

Dalam bentuk arus, algoritma yang disediakan adalah teknik peningkatan gradien sederhana pada kurva Vs (berhimpit dengan akhir fasa transien dari kendali). Titik awal algoritma tidak langsung secara iteratif disediakan oleh amplitudo, mencari cara yang secara periodik mengamati kurva daya terhadap tegangan. Dimulai dari titik sub optimal teridentifikasi, algoritma gradien meningkat sesuai dengan Vs untuk menemukan titik optimalnya, dan sekali titik optimal tetangga dicapai, demikian algoritma akan melacak perubahan lingkungan dengan memodifikasi Vs.

Anggap sebuah unit mulai dari situasi tanpa pengiriman daya (pada malam hari), Kendali CPU diaktifkan setiap Toff, detik (implementasinya 1 menit) melalui mekanisme waktu yang disurvei, dan sekali aktif, kendali CPU menyalakan converter dan memindai Vs untuk pengidentifikasian titik awal yang baik. Hal ini diselesaikan oleh penurunan Vs secara linier dari nilai maksimum ke minimum dan mengukur arus induksi Ib.

Tegangan yang terkait dengan nilai maksimum $\mathrm{Ib}$, adalah yang dianggap sebagai titik awal untuk algoritma gradient-ascent (karena $\mathrm{Vb}$ dapat dianggap konstan selama prosedur di sini tidak membutuhkan yang canggih mekanisme eksplorasi yang berbeda dipertimbangkan untuk rangkaian MPPT yang tidak sadar daya). Mode kendali gradien dengan Tgrad berparameter.

Sebaliknya, jika tidak ada daya yang dihasilkan, CPU akan mematikan konverter dan menunggu sinyal bangun berikutnya. Tindakan lebih jauh lagi, misalnya, berdasarkan algoritma yang dapat diprediksi secara 
optimal, pengaturan Toff bisa dipertimbangkan dalam rilis mendatang. Penginisialan algoritma tracking harus sesederhana mungkin untuk

alasan konsumsi daya, cukup cepat untuk mendeteksi dan melacak perubahan dan fleksibel untuk mengakomodasi sel surya yang berbeda (tipologi berbeda panel surya dapat dihubungkan tanpa perlu adapter elektronik). Algoritma yang dijelaskan perlu

disederhanakan dalam evaluasi gradien, operasi mahal dari sudut pandang konsumsi daya. Dalam arah ini, kita mengikuti pendekatan yang digambarkan, dimana hanya tanda dari gradien dianggap (karenanya menyerupai semacam aturan Hebbian).

Algoritma iteratif menyatu dengan nilai yang benar disediakan bahwa penguatan parameter memperkuat fungsi gradien yg cukup kecil. Terlebih lagi, kelengkungan di sekitar titik optimal adalah landai yang menyiratkan algoritma menjadi kuat (gangguan kecil diskrepansi antara Vs dan Vm tidak secara signifikan mengurangi efesiensi transfer energi). Mulai dari standar iteratif persamaan naik gradien:

$$
\left\{V_{s, i+1}=V_{s, i}+\Delta V_{s, i} \Delta V_{s, i}=\gamma \cdot\left(\frac{d}{d v}\left(i_{p, i}\right) \mid V_{s, i}\right)\right.
$$

Diperkirakan $\otimes V_{s, i}$ sebagai :

$$
\Delta V_{s, i}=\left\{+, \text { if }\left(V_{p, i}\right)>\theta-, \text { if }\left(V_{p, i}\right)>-0,\right. \text { lainnya }
$$

Sehingga tersedia,

$$
V_{s, i+1}=V_{s, i}+\Delta \widehat{V_{s, l}}
$$

Kedua operasi ini dicirikan oleh berkurangnya overhead CPU.

Untuk menjamin stabilitas, dijaga $\mid$ nilai minimumnya, yang diberikan oleh resolusi PWM DAC $\mid=$ $50 \mathrm{mV}$. Nilai yang kecil ini mengurangi kecepatan waktu respon dari sistem kendali, yang bagaimanapun dapat diterima sejak adaptasi maksimum waktu 20 detik ketika berangkat dari kondisi yang sepenuhnya cerah ke berawan dengan tingkat kecerahan rendah. Solusi adaptif tidak dapat dipertimbangkan dalam sistem saat ini untuk konsumsi daya overhead yang tidak dibayar kembali oleh keuntungan energik yang efektif.

Prosedur penurunan gradien berevolusi hingga gradien menjadi nol (di bawah ambang (). Jika tidak cukup energi yang berasal dari panel surya sel, CPU meninggalkan modalitas pelacakan dan kembali ke mode eksplorasi amplitudo untuk mengidentifikasi titik awal yang baru.

Dengan demikian, algoritma ini juga menyediakan mode pencegahan kegagalan terhadap ketidakstabilan dalam skema kendali gradien (yang akan memindahkan titik kerja di luar batas kurva daya, sehingga mengurangi nilai nol daya yang berasal dari sel).

Gradien diperkirakan melalui definisinya, di sini oleh pemaksaan lebih gelombang perturbasi ke variabel kendali dan mengevaluasi efeknya pada yang terkendali. Untuk mendeteksi tanda gradient, diadopsi operator korelasi, Karena korelasi yang positif merupakan gradien daya positif, sedangkan Relasi singkatan dari yang negatif (dan korelasi adalah operasi berbiaya rendah).

$$
X=\sum_{i=1}^{M_{p}} \quad \frac{\left|\delta i_{b}\right|}{\delta i_{b}}(i) \cdot \frac{\left|\delta V_{b}\right|}{\delta V_{b}}(i)
$$


di mana $\delta V_{b}=V_{b}(i)-\underline{V_{b}}$ adalah gangguan pada kerja titik ditumpangkan oleh CPU, $\delta i_{b}=i_{b}(i)-\underline{i_{b}}$ adalah gangguan induksi pada variabel terkendali dan $M_{p}$ adalah banyaknya titik-titik yang digunakan untuk membangkitkan sinyal gangguan. Parameter ( dan $\mathrm{M}_{\mathrm{p}}$, serta bentuk gelombang perturbasi, sudah diidentifikasi awal melalui simulasi SPICE. Setelah itu, parameter telah disempurnakan di lapangan untuk memaksimalkan performansi loop kendali (ketepatan reaksi dan stabilitas) dan memberikan akurasi dalam pengukuran saat ini.

Akhirnya, algoritma adaptif yang diimplementasikan dapat disintesis sebagai :

$$
V_{s, i+1}=\left\{V_{s, i}+\text {, if } X>V_{s, i}-\text {, if } X<V_{s, i}, \quad\right. \text { lainnya }
$$

Frekuensi dan bentuk gangguan yang ditumpangkan sangat penting karena konverter memerlukan fungsi transfer fase nol, dalam spektrum sinyal gangguan untuk beroperasi dengan benar.

\section{Hasil Dan Pembahasan}

Hasil penelitian dimulai dari pengambilan data tegangan keluaran solar panel, pada kondisi tanpa dan dengan menggunakan rangkaian MPPT terkendali adaptif. Gambar 5 menampilkan perangkat pengujian panel surya yang terdiri dari lampu, panel photovoltaic, rangkaian MPPT terkendali adaptif, osiloskop, dan multimeter. Proses pengujian menggunakan posisi lampu tegak lurus terhadap permukaan panel dan sejajar dengan titik tengah panel, durasi pengamatan dilakukan selama 60 detik.

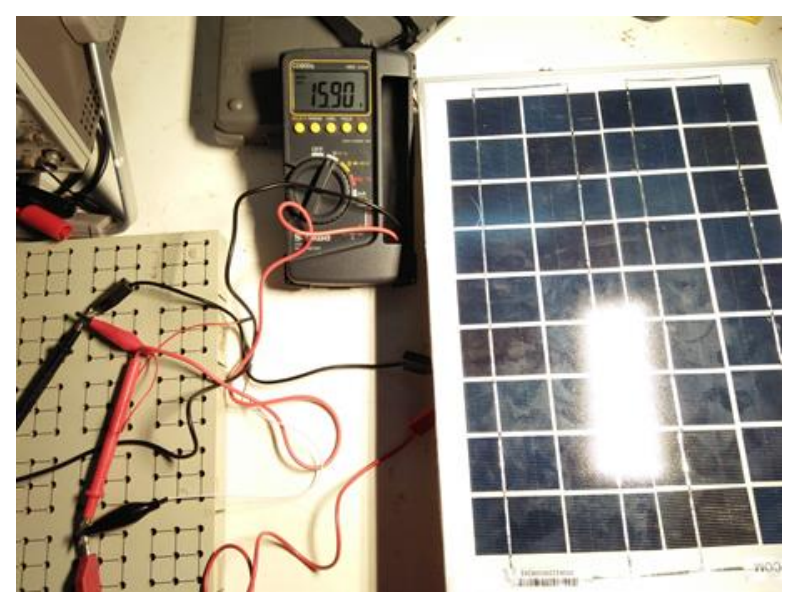

Gambar. 5 Perangkat Pengujian Panel Surya

Dengan implementasi rangkaian MPPT pada rangkaian yang menghubungkan antara solar panel dengan baterai, maka dilakukan pengujian alat dengan hasil sebagai berikut : 
Tabel 2. Hasil pengujian tegangan keluaran solar panel dengan tegangan keluaran Converter Buck DC-DC LM2596

\begin{tabular}{|r|r|r|r|c|}
\hline No & $\begin{array}{c}\text { Tegangan SP } \\
\text { (Volt) }\end{array}$ & $\begin{array}{c}\text { Tegangan LM2596 } \\
\text { (Volt) }\end{array}$ & $\begin{array}{c}\text { Selisih Tegangan } \\
\text { (Volt) }\end{array}$ & $\begin{array}{c}\text { Jarak Lampu } \\
\text { terhadap SP }(\mathrm{cm})\end{array}$ \\
\hline 1 & 3.430 & 3.284 & 0.146 & 38.5 \\
\hline 2 & 3.440 & 3.296 & 0.144 & 38.4 \\
\hline 3 & 3.461 & 3.312 & 0.149 & 38.25 \\
\hline 4 & 3.980 & 3.806 & 0.174 & 38.2 \\
\hline 5 & 3.482 & 3.333 & 0.149 & 38 \\
\hline 6 & 9.430 & 9.040 & 0.390 & 34.5 \\
\hline 7 & 9.440 & 9.050 & 0.390 & 34.4 \\
\hline 8 & 9.450 & 9.060 & 0.390 & 34.3 \\
\hline 9 & 9.460 & 9.070 & 0.390 & 34.2 \\
\hline 10 & 9.490 & 9.110 & 0.380 & 34.1 \\
\hline 11 & 9.510 & 9.120 & 0.390 & 34 \\
\hline 12 & 9.560 & 9.170 & 0.390 & 33.9 \\
\hline 13 & 9.570 & 9.180 & 0.390 & 33.8 \\
\hline 14 & 9.590 & 9.200 & 0.390 & 33.7 \\
\hline 15 & 9.600 & 9.200 & 0.400 & 33.6 \\
\hline 16 & 9.630 & 9.230 & 0.400 & 33.5 \\
\hline 17 & 9.640 & 9.240 & 0.400 & 33.4 \\
\hline 18 & 9.650 & 9.250 & 0.400 & 33.3 \\
\hline 19 & 9.660 & 9.260 & 0.400 & 33.2 \\
\hline 20 & 9.670 & 9.270 & 0.400 & 33.1 \\
\hline & 8.057 & 7.724 & 0.333 & Rata-rata \\
\hline
\end{tabular}

Dari tabel di atas dapat disimpulkan bahwa semakin dekat jarak cahaya dari solar panel, makin besar pula tegangan keluaran yang dihasilkan, baik tegangan keluaran pada solar panel, maupun tegangan keluaran pada rangkaian MPPT terkendali adaptif, dengan rata-rata selisih tegangan yang dihasilkan adalah 0,333 Volt. Dari table data tersebut dapat diperoleh grafik pada gambar 6 sebagai berikut :

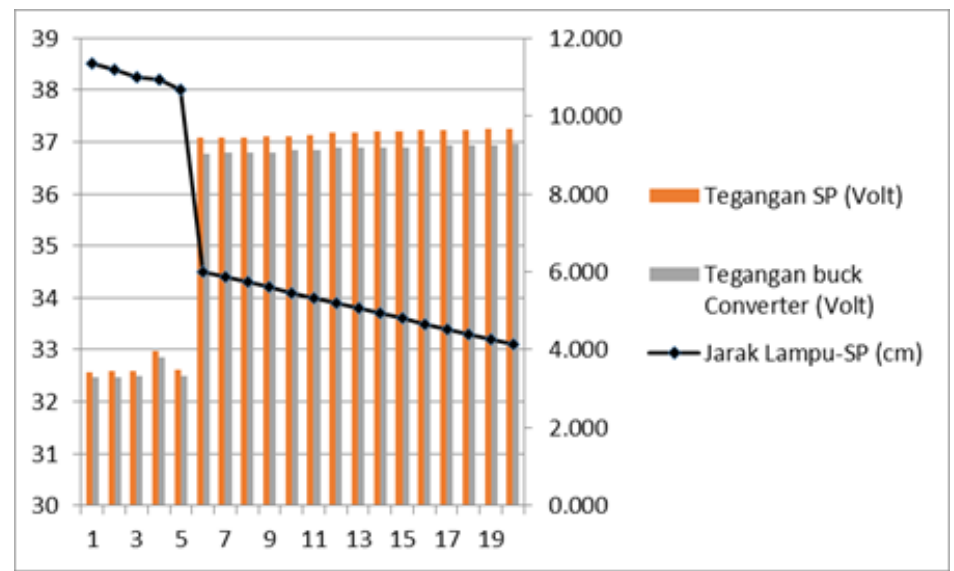

Gambar. 6 Grafik tegangan keluaran solar panel dan buck converter terhadap jarak lampu - solar panel(SP).

Dari tabel data dan grafik tersebut, maka diperoleh rata-rata tegangan keluaran solar panel sebesar 8,057V, sedangkan rata-rata tegangan keluaran Buck Converter sebesar 7,724V. Jika dibandingkan dengan kebutuhan catu node WSN, ditinjau dari spesifikasi baterai sebesar 7,64V, maka dapat disimpulkan bahwa keluaran sistem MPPT memenuhi syarat untuk dijadikan sebagai sumber pencatuan baterai pada node 
WSN. Kemudian didapatkan bahwa jarak optimal untuk mendapatkan tegangan yang sesuai proses pencatuan adalah pada jangkauan jarak $34,5-38 \mathrm{~cm}$. Tentu saja hal ini berlaku dalam lingkup di dalam ruangan, dengan mengasumsikan lampu sebagai matahari.

Dengan membandingkan antara data tegangan keluaran solar panel dengan MPPT, dengan data tegangan keluaran solar panel tanpa MPPT pada kondisi penyinaran, disimpulkan bahwa tegangan keluaran solar panel tanpa MPPT lebih tinggi dibandingkan dengan menggunakan MPPT (15,81V). Namun yang menjadi prioritas penelitian terletak pada kekonsistenan solar panel dalam menyediakan tegangan yang dibutuhkan untuk mencatu node WSN. Dalam pengujian, ditemukan bahwa solar panel tanpa MPPT menghasilkan tegangan keluaran yang fluktuatif, karena bergantung pada intensitas cahaya matahari yang diterima oleh solar cell.

\section{KESIMPULAN}

Berdasarkan hasil penelitian yang telah dilaksanakan, diperoleh kesimpulan bahwa implementasi MPPT pada keluaran solar panel mampu menjaga tegangan keluaran lebih konsisten (tidak fluktuatif), dengan ratarata selisih tegangan $0,33 \mathrm{~V}$. Selain itu, jarak dan intensitas cahaya sangat berpengaruh terhadap tegangan keluaran solar panel. Semakin dekat jarak cahaya terhadap solar panel, makin besar tegangan yang dihasilkan. Berdasarkan hasil penelitian, tegangan maksimal yang dihasilkan solar panel dengan menggunakan rangkaian MPPT sebesar 9,27V.

\section{UCAPAN TERIMAKASIH}

Melalui kesempatan ini, saya mengucapkan terima kasih kepada Tim JTECE, yang telah memberikan kesempatan kepada saya untuk dapat mempublikasikan jurnal saya.

\section{Daftar Pustaka}

[1] Z. Farooqui, Study of MAximum Power Point Tracking (MPPT) Techniques in a Solar Photovoltaic Array, Vol.2, . 2017.

[2] J. H. J. F. M.S.V.Ragunathan, A. KAnsal, "Design Considerations for Solar Energy Harvesting Wireless Embedded Systems," in IEEE Int.Conf.Inf.Process Sensor Netw., 2005, pp. 457-462.

[3] A. Soetedjo, A. Lomi, Y. I. Nakhoda, and A. U. Krismanto, "Modeling of Maximum Power Point Tracking Controller for Solar Power System," TELKOMNIKA (Telecommunication Comput. Electron. Control., vol. 10, no. 3, pp. 419-430, 2012.

[4] J. D. V. W. P.N.M.N.K. Lujara, "Power Electronic Loss Models of DC-DC Converters in Photovoltaic Applications," in IEEE Int. Symp. Ind. Electron, 1998, pp. 35-39.

[5] T. S. and K. U. M. Veerachary, "Neural-network-based maximum-power-point tracking of coupled-inductor interleavedboostconverter-supplied PV system using fuzzy controller," IEEETrans. Ind. Electron, pp. 749-757, 2003.

[6] J. H. R. Enslin and D. B. Snyman, "Combined low-cost, high-efficient inverter, peak power tracker and regulator for PV applications,” IEEETrans. Power Electron, vol. 6, pp. 73-82, 1991.

[7] D. B. S. and W. S. J. H. R. Enslin, M. S. Wolf, "Integrated photovoltaic maximum power point tracking converter," IEEETrans. Ind. Electron, vol. 44, pp. 769-773, 1997.

[8] H. D. and E. F. F. M. A. S. Masoum, "Theoretical and experimental analyses of photovoltaic systems with voltage- and currentbased maximum power-point tracking," IEEE Trans. Energy Conv., vol. 17, pp. 514-522, 2002.

[9] Y. H. Lim and D. C. Hamill, "Synthesis, simulation and experimental verification of a maximum power point tracker from nonlinear dynamics," in Proc. IEEE 32nd Annu. Power Electron. Specialists Conf., 2001, pp. 199-204.

[10] W.-S. K. and H.-S. K. C.-Y. Won, D.-H. Kim, S.-C. Kim, “A new maximum power point tracker of photovoltaic arrays using fuzzy controller," in Proc. 25th Annu. Power Electron. Specialists Conf., 1994, pp. 396-403.

[11]C. Alippi and C. Galperti, “An Adaptive System for Optimal Solar Energy Harvesting in Wireless Sensor Network Nodes,” IEEE Trans. Circuits Syst. I Regul. Pap., vol. 55, no. 6, pp. 1742-1750, 2008.

[12] Ashari M., Desain Konverter Elektronika Daya. 2017. 